\title{
Contemporary Studies on Suburban (Indonesia) Today: Critique on Classical-Neoclassical Regional Economics Based Institutional Economics Perspectives
}

\author{
${ }^{1}$ Pitri Yandri, ${ }^{2}$ D.S. Priyarsono, ${ }^{3}$ Akhmad Fauzi, ${ }^{4}$ Arya Hadi Dharmawan \\ ${ }^{1}$ STIE Ahmad Dahlan Jakarta, P.hD Student of Regional \& Rural Development \\ Planning Sciences, Bogor Agricultural University (IPB) \\ ${ }^{2}$ Dept. of Economics, Faculty of Economics and Management IPB \\ ${ }^{3}$ Dept. of Resource and Environmental Economics, Faculty of Economics and Management IPB \\ ${ }^{4}$ Dept. of Socio-Economic Sciences, Faculty of Human Ecology IPB \\ Corresponding Author: p.yandri@gmail.com,
}

Recieved: January 2018 | Revised: April 2018 | Accepted: July 2018

\begin{abstract}
The current trend shows that the growth of suburban area is increasingly massif, both its total areas as well as quantity. However, the phenomenon is not followed with the attention of researchers to conduct the study on it. Even if there is, their attention escape on an important approach in the analysis. Their analysis rests on old theories which assume that the space planning and land just triggered by the company's and household's behavior. Nonetheless, the fact remains that land use planning involves complex functions of institution. Therefore, this brief article reports the results of a literature review about the condition of suburban areas in Indonesia. The approach is conducted by critical review using institutional analysis to elaborate classical and neoclassical regional economic theories, as well as comparing and synthesizing the literature. To sharpen the argument, I also present the relevant descriptive data. Through institutional perspective, I argue that the real question of land use planning and its development in the suburbs exists beyond land and infrastructure issues.
\end{abstract}

Keyword: von Thunen; land rent; suburbia; formal institution; informal institution; decentralization JEL Classification: B12, B13, B15, R11, R110

How to Cite: Yandri, P., Priyarsono, D., Fauzi, A., \& Dharmawan, A. (2018). Contemporary Studies on Suburban (Indonesia) Today: Critique on Classical-Neoclassical Regional Economics Based Institutional Economics Perspectives. Jurnal Ekonomi Pembangunan: Kajian Masalah Ekonomi dan Pembangunan, 19(1), 80-93. doi:https://doi.org/10.23917/jep.v19i1.5701

DOI: https://doi.org/10.23917/jep.v19i1.5701

\section{Introduction}

In Indonesia, the study of suburban area is relatively uncommon because the attention of many academics is focused on either rural or urban issues. The reason why most discourse phenomenon and empirical research are only focused on those areas is rural areas are regarded as main resources provider for cities and towns, especially food. That situation makes rural areas are considered very important in contributing to the sustainability of food availability in Indonesia. Therefore, any attempt to solve the problems of the countryside through a variety of research is highly regarded.

On the other hand, in the perspective of structural transformation, urban areas are 
Jurnal Ekonomi Pembangunan: Kajian Masalah Ekonomi dan Pembangunan, 19 (1), 2018, 80-93

considered as a major factor for economic growth; hence, resolving various problems of urban areas will thus contribute to the efforts of helping economic growth. Observing the situation, we can clearly see the suburb as an 'intermediary' between the two areas (rural-urban), and thus serious attention for the suburb becomes crucial. Moreover, in the context of the implementation of autonomy and decentralization, the emergence of small cities will also creates new suburban areas.

In the same context, Joko Widodo's administration has introduced Nawa Cita (Nine Agendas) which promotes the concept of "developing from the periphery". Developing from the periphery gives high priority on the outskirts as opposed to central areas (Priyarsono, 2017). Moreover, Priyarsono (2017) argued that there is no formal definition for the concept of developing from the periphery, thus the concept can be understood from a variety of perspectives. Developing from the periphery can be seen as an attempt to build rural areas, in which the central areas are considered as the urban. In the context of this article, it may be declared the area of the suburb is the periphery, and the urban areas is the center. On the basis of this simple understanding, not to mention that the formal boundaries of the concept of "periphery" in Nawa Cita is still undefined, any perspective on the concept of "periphery" will still contribute to the agenda of Nawa Cita.

The emergence of the suburban areas as area of interaction between rural and urban areas is extremely complex in nature. It involves both socio-economic and spatial issues. In a study of literature on suburban, Hinchcliffe in Vaughan (2009) argued, "The literature of the suburbs is extensive, yet the subject always seems elusive. For some the suburbs is a geographical space; for others, a cultural form; while for others still it is a state of mind."

In theory, terms associated with suburban are used much differently by academics. Terrence Mcgee (1991) in Ortega (2012) introduced the term "desakota". The concept of a desakota is a "mixture of intensive agricultural and nonagricultural located along the corridor of big cities", and "residents along the corridor is moving (engaging) in agriculture". This concept was later used by Hudalah \& Firman (2012) in their studies in Jakarta Metropolitan City. Other terms for the suburbs are "urban fringe" and "peri-urban", which is frequently used in many articles for different contexts. The term "suburb" is also used by Sonmez (2009) in observing a suburban area of the city of Izmir, Turkey.

Due to various terms that illustrates the concept of suburbs, clear definition becomes very important. According to Ann (2013), clear definition will certainly be useful in (1) the issue of policy making; (2) the formulation of the research problem and theory; and (3) the field study, although one may argues that clear definition is important only for theory. From the results of the analysis, defining the suburban comprehensively turned out as a task that was not easy to be done. However, Ann (2013)—referring to Harris (2010) - stated that in the search of the definition of suburbs, approaches on location, density and novelty can be utilized.

In this case, approach on location could be more consistently applied because naturally, suburbs' development activity are done outside the urban or metropolitan area. The question is, how far or wide is the suburban area? The answer depends on the number of existing metropolitansized cities, the size of the town centre, and the forms of transportation. Therefore, Ann (2013) try to parse it into subdefinitions with a fixed reference to Harris' principles (2010), which are density and novelty. Harris stated, although not common, some urban areas have a denser suburban area than the city centre. From the aspect of novelty, how old a suburb can be part of a city's suburban history? It comes down to the location and relative novelty that have landscape functions, mode of transportation, social character and specific physical features. 
Table 1. Approaches to Defining Suburbs

\begin{tabular}{lll}
\hline & \multicolumn{1}{c}{ Esensi } & \multicolumn{1}{c}{ Fitur dan Jenis } \\
\hline What a suburb is/positive & $\begin{array}{l}\text { Example: low density primarily } \\
\text { residential areas. }\end{array}$ & $\begin{array}{l}\text { Example: first, second, and third } \\
\text { ring suburbs; suburbs as low } \\
\text { density, with detached houses, } \\
\text { middle class families, substantial } \\
\text { open space, and scattered } \\
\text { employment. }\end{array}$ \\
What a suburb lacks/negative & $\begin{array}{l}\text { Example: Suburbs are within } \\
\text { metropolitan areas (not rural) } \\
\text { and outside the central cities (not } \\
\text { core) }\end{array}$ & $\begin{array}{l}\text { Example: not cultured, not diverse, } \\
\text { unequal, not dense. }\end{array}$ \\
\hline
\end{tabular}

Table 2. Key Dimensions for Defining Suburbs with Examples of Definition

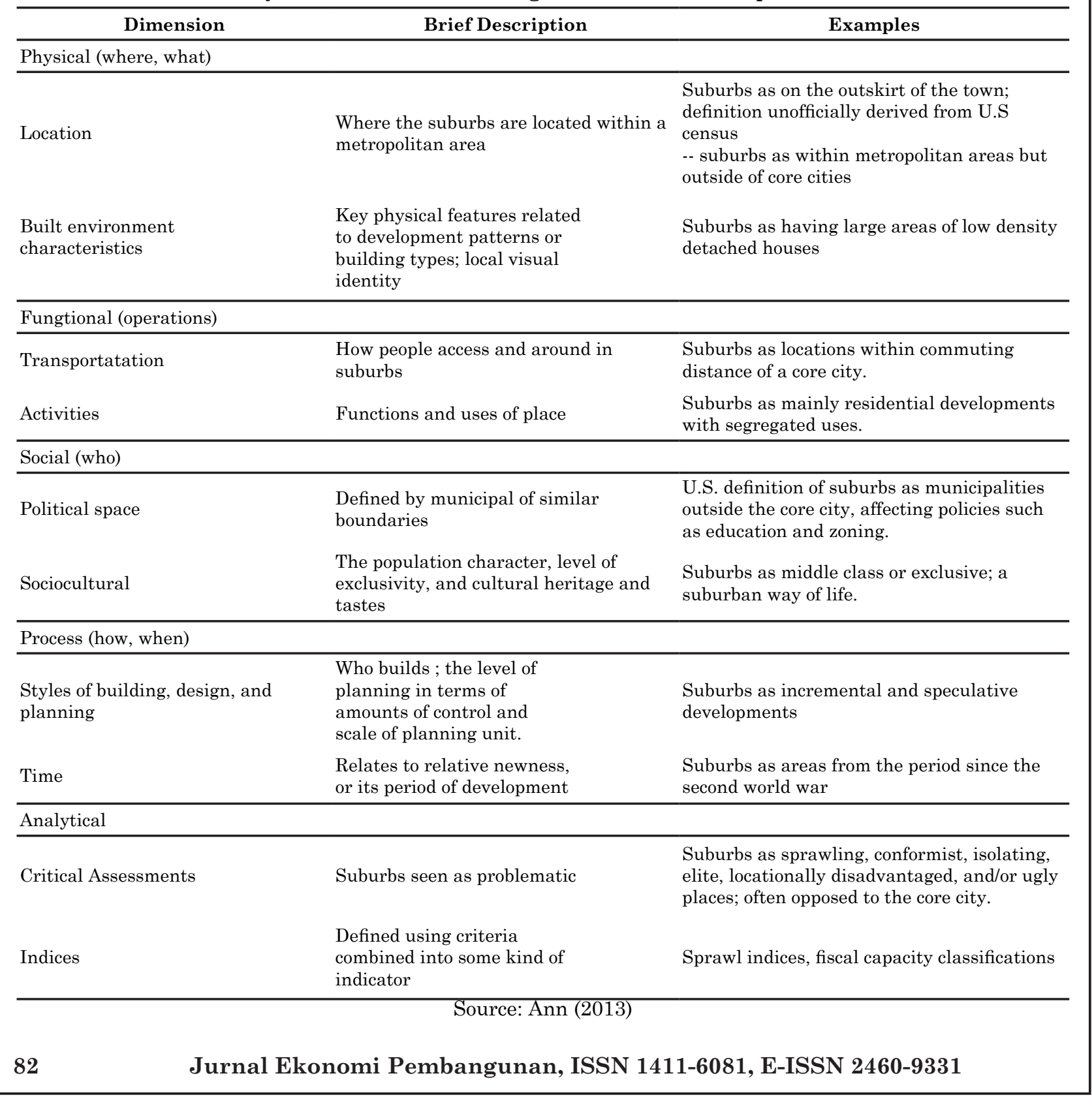




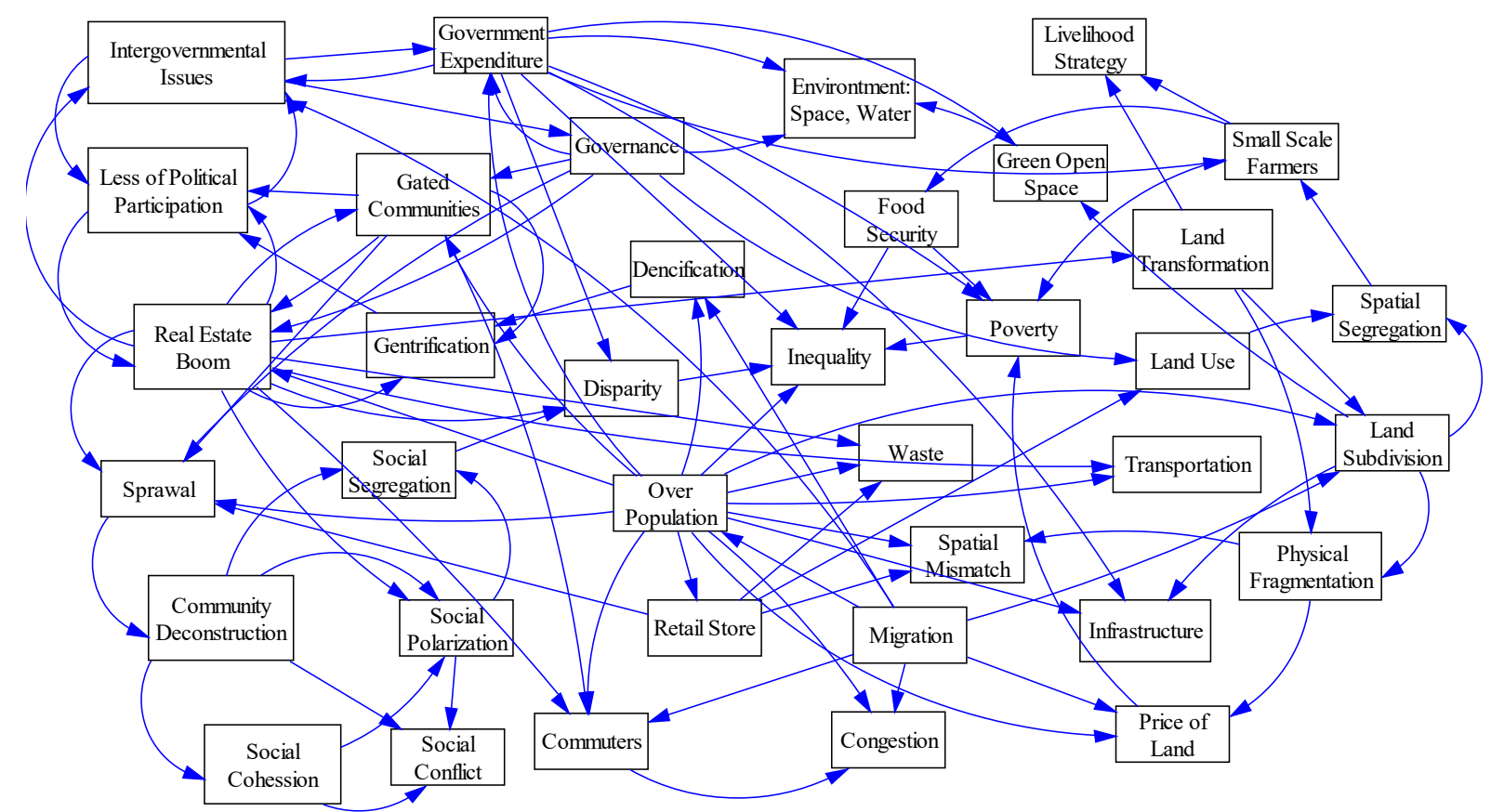

Figure 1. The dynamics and complexity of problems in the Suburban Area Source: the analysis of the literature, proceed by Vensim, 2017

Next, Ann (2013) are trying to dissect the concept of "suburban" from different perspectives. According to Ann, the two approaches that are relatively good for defining the suburb can be seen from the positive and negative sides (Table 1). Ann (2013) and other literature-based studies provide key dimensions to define suburban with a few examples of such definitions. Those dimensions are physical, functional, social, process, and analytical scopes. In the end, that explanation is detailed enough to elaborate the concept of suburbs. The Table 2 below describes the dimensions.

In the context of developing countries, particularly Indonesia, current trend shows that the growth of suburban area is increasingly massif, both its total areas as well as quantity. Further inspection regarding the territory has showed that the expansion of the functions of the metropolitan area continues to suppress the surrounding areas. This in turn alters the structure of economic, socio-cultural, ecological and spatial areas in the suburbs. Meanwhile, the increase of the number of suburban areas seems to be tightly related to the major change of governance in Indonesia, originally from a centralized framework to decentralized autonomous region. These changes cause many areas to extract themselves and form a new administrative area. As a result, many of those propose to form the "downtown" area (municipal).

Data from Ministry of Home Affairs Republic of Indonesia (2016) confirmed that since the regulation of decentralization and autonomy was first implemented, the number of municipal area increased from 61 to 94, or an increase of around $54 \%$. In addition, Bappenas estimates that the number of metropolitan cities and cities will increase sharply by 2025 (Bappenas, 2015). The implication is that the increase of the number of municipal were followed by the expansion of the functions of its territory, and thus the demand for various functions from the buffer area around municipal also increased. The increase in demand of functionality naturally implied that there was also an increase in complexity of problems faced by the suburban area.

The complexity of the problems in the suburbs seems to be indeed a common phenomenon in developing countries. Literature studies on developing countries with high population density provide information that the problems are very 
multidimensional. In Bangkok, Thailand for example, land transformation process studied by Hara et al., (2008), and it was concluded that land planning (landscape) in the suburban area was needed. In other contexts, for example in Brazil, although marked by high quality transportation infrastructure and its connectivity, the dynamics of the social-ecological problems its suburban was even more severe. High density of population, weak law enforcement, high level of poverty and unemployment had been converted into high rates of criminality and middle-class residents' dependency on alcohol (Silva et al., 2012). Illustration of the complexity and interconectedness of issues and problems in suburban areas is illustrated in Figure 1.

A number of studies showed that the growth of the suburban area in massive scale had an impact on the whole dimension of life, whether environmental, spatial, economic, ecological-sociocultural, and even political. The real impact on the environment, studied by Garcia et al. (2013), attested to the suburban growth was the change in water consumption patterns. These changes were caused by the increasing population growth in suburban areas.

Spatial impact of the growth of the suburban area was indicated by the pressure on land (Day, 1996), the rise of sprawl (Giyarsih, 2002; Hiles \& Schipper, 2008; Astuti, et al., 2012, Lambert et al., 2015), and land conversion (Mugavin, 2002), including agricultural lands (Ortega, 2012; Eltayeb, et al., 2013, 2016, Liu Liu \&), as well as the spatial mismatch (Mikelbank, 2006).

On a microeconomic level, the growth of suburban areas promoted growth of industrial area (Hudalah \& Word, 2012), including the massive growth of retail stores (Smadja \& Torre, 2017), and changes in consumption patterns as a result of the emergence of a group of middle-class citizens with high-middle income level (Ospala \& Dufek, 2002; Hirt, 2007). Meanwhile on the macroeconomic level, the growth of suburban areas had an impact on the increase of government spending (and municipalities) in an effort to rehabilitate public service facilities (Lambert et al., 2015). In addition, studies conducted by Surya (2006) stated that the growth of suburban areas would encourage the growth of transportation needs. It arose as a result of people commuting from the suburbs to the centre to work (commuters) (Chan et al., 1992; Myung, et al., 2013).

Socially and ecologically, the growth of suburban areas thus increased poverty (Curley, 2005), changed livelihood strategy of a community who work in the agricultural sector (Eltayeb et al., 2013, 2016, Liu Liu \&), depressed social capital (Clark, 2007), put a pressure on the minority groups (Ragusett, 2014), urged the rise of real estate and housing cluster (Leisch, 2002; Goix, 2005, Huang \& Jiang, 2009; Serlin \& Umilia, 2013; Güzey, 2014), created economic and income inequalities (Huang \& Jiang, 2009; Kathryn, 2009; Yandri, 2014; Zhao, the 2016) as well as social segregation (Yandri, 2015), housing segregation (Hwang, 2015) and in-group exclusivity (Gunawan (2011), all of which culminated the emergence of social tension (Widhyharto, 2009; Yandri, 2015).

Politically, the growth of suburban areas, one of which is marked by the emergence of the residential real estate and/or housing clusters, resulted in a low level of political participation by citizens because of a situation referred to as gentrification (Schram, 1991). A study of the situation was verified by studies conducted Newman, et al. (2013) in the United States and Yandri (2017) in the city of South Tangerang, Indonesia.

\section{Methods}

This brief article reports the results of a literature study on the condition of suburban areas in Indonesia. Article is presented by doing a review on the relevant literatures. The approach is done by doing a critical review using institutional analysis as the tool to elaborate classical and neoclassical regional economic theories, as well as comparing and synthesizing the literature. To sharpen the argument, the writers also present the relevant descriptive data. 


\section{Result and Discussion}

In classical economics, the explanation of the functionality over the location of the land was described by von Thunen (1783-1850). Therefore, discussing thesuburbsseems to be related to theland use theory developed by von Thunen. Furthermore, this theory explains the interconnectedness of location production (agriculture) with the center in an effort to achieve maximum profit growth (land rent). The theory states that the farther a farmland with central growth area, the lower the rent obtained by farms. The theory elaborates the farm distribution patterns near the urban areas. The real illustration of the theory is the curve reflecting the relation between distance and rent of a land. The illustration for the theory above can be explained by the curve of the rent generated from a production system (Figure 2). The von Thunen theory then evolved and was adapted in a variety of phenomena, including rural-urban linkages. On the basis of that theory of von Thunen, Walter Christaller (1933) introduced the central-place theory that explains the patterns of the locality of economic activities (Blair, 1991).

Problems wanting to be solved by von Thunen are: land use and cropping pattern as to what will happen to these conditions and how farming systems in the different districts are affected by distance from the city (with the assumption that farming is regulated rationally). From the hypothesis and the problem, the assumptions made are: (1) the city center as marketing, located in the centre of a geographically homogenous area. The central part is depicted as the centre of settlements as well as industrial center that is also the center of the market; (2) the cost of transportation (to transport results from production sites to the city) is proportionally linear with the distance. Every farmer in the areas surrounding the city will sell the excess products to those cities while paying the transportation costs; and (3) farmers rationally tend to choose plants that generate maximum profit (Rustiadi et al., 2011).

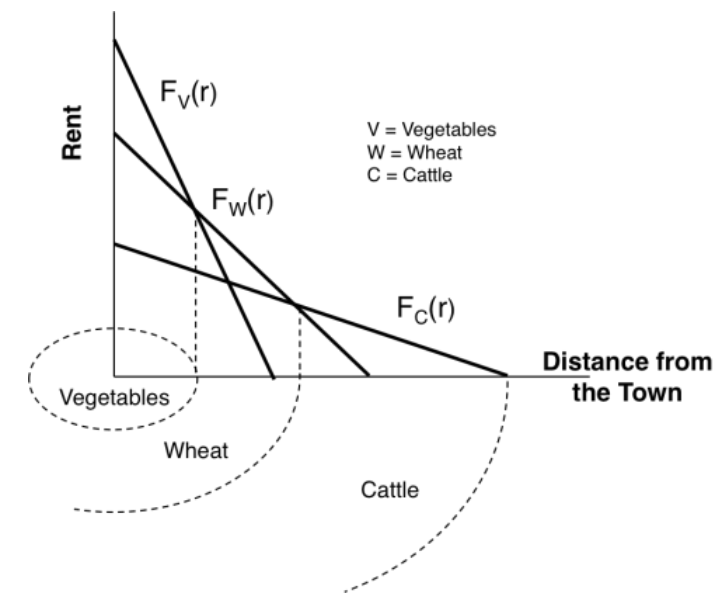

Figure 2. von Thunen's Distance-Rent Curve

However, many critics argue that this theory is no longer corresponds to the reality of the present, especially if associated with the reality of the existence of the revolution industrialization and economic development. The industrialization of the middle world is currently faced with particularly high technology use of transportation, the revolution in the organization of human resources, and human behavior. The fact is that there is currently significant modern suburban area that is different than what was experienced by von Thunen. Moreover, most urban areas are experiencing an expansion of territory, so that the nature of the urban expansion is determined by: (1) the difference in the price of land in the urban area and rural; (2) motor vehicle transport flexibility offered land users; and (3) assessment and human desire (Sinclair, 1967).

In further development, the land was then rated as production factors in encouraging economic growth, apart from the factor of labor and technology. Model from Robert Solow (1956) later became the explanatory framework for the theory of economic growth. The reading of the literature of economics, especially its relation to the predictive models of economic growth, and the thought-provoking Solow model always is used, and it is the point of departure for nearly the entire economic growth analysis, including an analysis of 
Jurnal Ekonomi Pembangunan: Kajian Masalah Ekonomi dan Pembangunan, 19 (1), 2018, 80-93

the regional economic growth. The Solow model is then in a variety of economic literature referred to as neoclassical economic model. If drawn on a regional level, the Solow model can provide an explanation of the fundamental and the important. It is caused by the understanding that regional output certainly in the neo-classical view is based on or influenced by three components: the growth of the capital stock, the growth of employment and technological development.

Therefore, in neoclassical economic theory, it is known the function of production $Q=f(K$, $\mathrm{L}, \mathrm{T}, \ldots)$, where $\mathrm{K}$ is capital, $\mathrm{L}$ is labor, and $\mathrm{T}$ is technology. The main unifier in this model is actually the achievement of long-term economic growth that are experiencing convergence, i.e. price mechanism, and capital accumulation mechanisms, which is foreseen will take on a situation that is convergent (ratio of capital in relation to labor is uniform) (Priyarsono, 2017).

Nevertheless, the forecast form Solow model is difficult to be attained because various factors, such as the model is not able to explain the diversity of the inter-location, which is spatially natural (Priyarsono, 2017). In addition, the Solow model puts economic growth (output) as the best indicator in economic development. However, economic development must be measured by other indicators, such as the human development index (HDI), and so on. Therefore, Rustiadi et al., (2011) argues that the pursuit of development priorities tend to pursue the goals of macro (economic growth), which in turn can lead to a variety of development imbalances in the form of the spike of spatial disparity, rural-urban disparity, structural inequalities and so on.

On the level of regional economic theory, weakness of this model's prediction were later perfected by Walter Isard (1956) in Rustiadi et al., (2011) by saying: "the existence of the fact that human beings in performing its activities adapt and interact with the physical environment, is a strong reason over the need for the formulation of comprehensive theory that consider aspects of human, physical and economic.
In the span of one year thereafter, Gunar Myrdal (1957), as cited by Rustiadi et al., (2011), argues that the neoclassical model actually gives birth to what he termed the backwash effect as a result of international and interregional demonstration effect. Myrdal's argumentation is that the nature of the community in underdeveloped regions tend to emulate consumption patterns among the modern society in the region that is more advanced, so that those territories import goods from the more modern territory. Finally, the accumulated capital is not used to boost economic growth in its territory by purchasing local products, but instead it is leaked to outside the area. This theory was later called as regional leakages. The phenomenon, according to Myrdal, widen the inter-region disparity.

In the same decade, Francois Perroux (1955) introduced the Growth Pole Theory. The core of this theory states that economic growth in each region does not occur at any place except in a specific location called the pole of growth. To achieve a high level of income, economic activity center called polar growth (growth pole) should be built. Perroux's view about the growth process is a theory of spatial economy, where industries are the driving role early in building a centre of growth. Geographically, growth pole can be described as a location that has the facilities and advantages so as to cause an attraction for many people to set up a wide range of businesses in the area, and thus the public utilizes these facilities. Functionally, the growth pole can be defined as a place of concentration of economic groups (industry, business etc) resulting in economic influence into or out of the region (Blair, 1991).

Furthermore, in the respond for the neoclassical macroeconomic model incompleteness, economic scientists then developed region-based economic analysis. For example, Arthur Lewis (1967) in Blair (1991) argued that the development of a region would have experienced stagnation when only one sector are developed. Therefore, according to Lewis, the development of the region can be achieved if other economic sectors are also growing. 


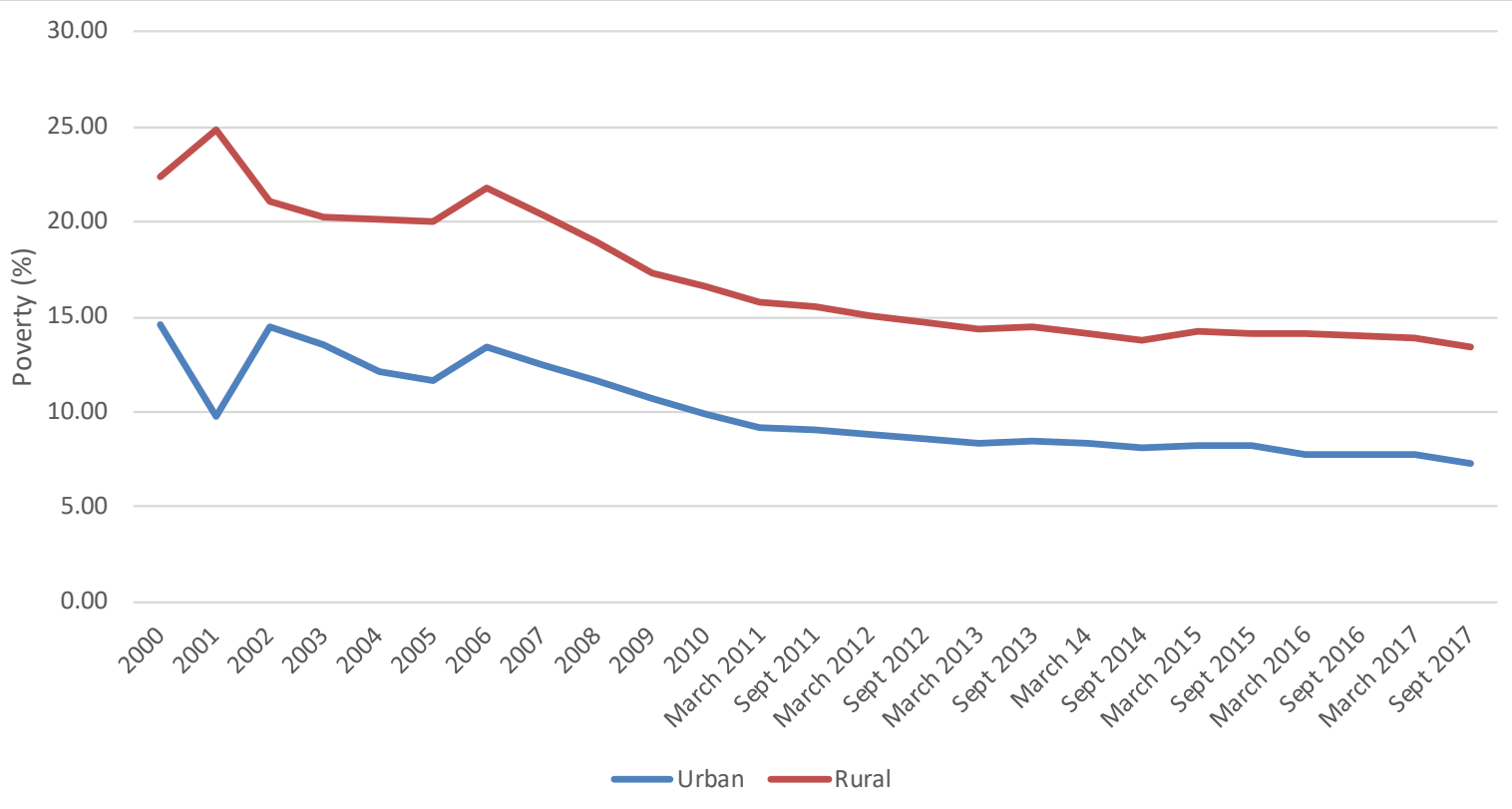

Figure 3. The percentage of poverty in urban and Rural in Indonesia Source: BPS, 2018

At the next stage, the economic base theory put forward by Harry w. Richardson (1973) in Blair (1991) states that the primary determinants of economic growth in a region is directly related to the demand for goods and services from outside the region. In further explanation, it was elaborated that the growth of industries that use local resources, including manpower and raw materials for export, will generate the wealth of the region and the creation of job opportunities. This assumption gives the notion that an area will have the leading sector (basic sector) if they can win competition on the same sectors in other regions so as to produce exports.

In Indonesia, especially at the level of policy, neoclassical economic views were able to bring the nation to wealth. The empirical facts shows that economic growth reached $7.1 \%$ at the end of 1996 . From that indicator, the nation-state is judged to have reached a stadia which according to Rostow (1960) as a "take off" stadia. Nevertheless, the choice of "economic growth" as an end thus cause new problems, namely the wide disparity between regions, with regional or interregional centre in Indonesia. The economic crisis followed by a social crisis in the year 1997-1998 is a real confirmation that the neoclassical theories fail in realizing economic development. The situation led to an understanding, both at policy makers or scientists that the nation-state will need to reform themselves.

Therefore, the essential point fort the change in Indonesian development patterns began in 2001, marked by an era of autonomy and decentralization with the passage of the Act No. 22/1999, then revised to Act 32/2004; and revised back into the Act No. 23/2014 about local governance and Law No. 33/2004 (revision of the Act No. 25/1999) regarding Financial Equalization between the Central Government and Regions. The second act aims to address the disparity between the centre (vertical imbalance), and interregional disparities (horizontal imbalance).

However, the implementation of fifteen years of autonomy and decentralization apparently has yet to show satisfactory results. It is indicated by the still unequal distribution of the development cake between rural and urban areas in Indonesia. Publication of the data of the Central Bureau of Statistics (BPS) in November 2011 shows that 
the countryside was still suffered from severe poverty levels rather than urban areas. In 2009 for example, the number of poor population reached 20.62 million inhabitants in rural and 11.91 million in urban areas. In 2010, the number decreased to 19.93 million inhabitants in the rural and the urban in 11.10. While at 2011, the numbers were 18.97 million inhabitants in rural and 11.05 million in urban areas. Until September 2017, although the total number of the poor population decreased, the situation was still the same, that is, the number of poor population in rural areas (16.31 million) were higher than urban (10.27 million).

High rates of poverty as a result of the low employment opportunities and the level of wages is the cause for the poor population in rural areas to migrate to the cities. The phenomenon of migration is a form of response from the society due to their expectations to increase their livelihood. In other words, rural-urban migration will continue to progress along the on-going rural-urban development gap (Rustiadi, 2011), in addition to the problem caused the perception that the city is the main source of wealth (urban bias) (Fauzi, 2010).

In the empirical context, DKI Jakarta as the centre of growth in trade and services in Indonesia, is a region that receives the spill-over of migration flows. Data from Population and Civil Registration Agency of DKI Jakarta shows that population in 2010 reached 9.6 million people and this number increased to 10.17 million in 2015 . The average rate of population growth in Jakarta from the year 2010 up to 2015 reached $1.09 \%$ per year. With that population growth rate, the population density reached 15.36 persons per square kilometre.

The decrease in availability of space and land, coupled with the high price of land in Jakarta (Figure 5 and 6) in turn will encourage residents to move to the outskirts of the city (suburb). This process is seen as an expansion of the urban area (Jakarta) to suburban areas, impacting a wider scale of urban area management in real terms. This process is often valued as a contradictory process considering the process is always accompanied by the conversion of agricultural land. The phenomenon is referred to as suburbanization, defined as the process of the formation of new settlements and industrial area on the edge of urban areas mainly as a result of the displacement of the population who need a place to settle and establish industrial activity (Rustiadi et al., 2011).

Analysts are to argue that the phenomenon is unavoidable because the process is created as a result of the demand and supply in the market. For them, in many aspects, it would have a positive impact because it will create an economic agglomeration which produces additional resources in such as human capital that can serve as the engine of economic growth (World Bank, 2009). This perspective, as read in the thought of Robert Lucas (1967-1981) through its economic growth theory (Andrada, 2017). For him, in the long run this process will be produce convergent economic growth. As for Lucas the mobility of labor and capital will help the economic concentration, and this flow will mitigate the differences in wellbeing that can accompany it. At the level of policy, this perspective would produce policies such as facilitating the migration and make clustered immigrants who have skills and well educated (World Bank, 2009). In the present terminology, this is referred to as "demographic bonus" (Jati, 2015).

Nevertheless, the convergence does not happen by itself, because it requires institution to manage the existing economic resources (land, and investment in infrastructure), on the right track and well-managed intervention (World Bank, 2009). The prerequisite of good governance becomes the starting point for the realization of the convergence. Inaccuracy intervention such as mis-allocative investment in many ways thus worsening the situation changes in social, economic and spatial in suburban areas (Lewyn, 2017) 


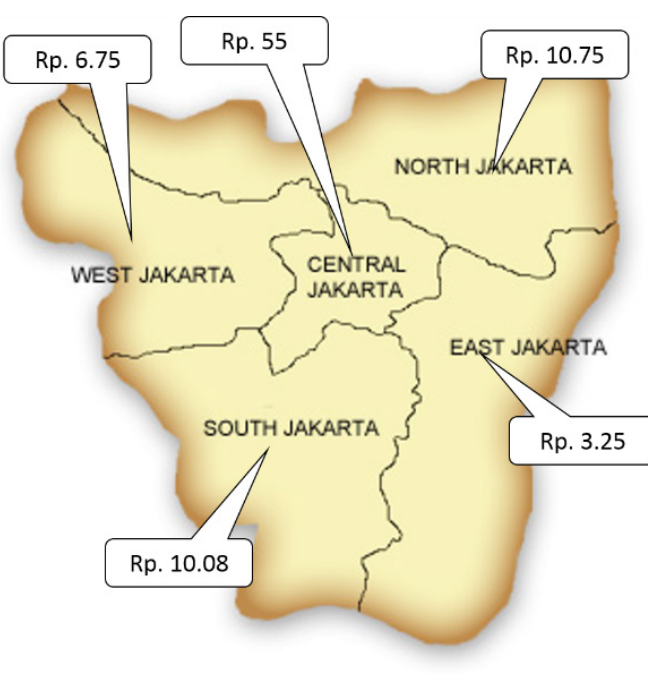

Figure 4. The average price of land per $\mathrm{M}^{2}$ in Jakarta in 2015 (in million Rupiah)

Source: Map: http://citiviu.com Land price: www.rumah.com

Lewyn's hypothesis (2017) has been proved in Indonesia. Parallel with the high demand of land, economic opportunities is taken by local governments by providing investment permit for developers of both industries and settlements. Opening the investment valve is certainly intended to enlarge the income from tax through expansion of the area of the region, particularly the Land and Building Tax (PBB). In the context of the implementation of decentralization and autonomy, it is justified because it has been set in the regulation, either by law or other specific regulations. On the basis of this reason, the local government issued a variety of policies in order to encourage increased investment. One set of the policies is streamlining investment permit and in certain cases makes it easier by providing online service for applying investment permit.

Therefore, in the context of economic development, current construction practices and land planning was triggered by not only the company's behavior and the behavior of households as assumptions in such theories, but also the behavior of the government (Priyarsono, 2017). Referring to Sinclair (1967) and Priyarsono (2017), this indicates that the planning of land and area involves complex functions of institutions, which includes social capital, loyalty and learning regions, power relations and control in the organization, as well as organizational culture, norm and rules (Stimson et al., Priyarsono in 2016, 2017). By that explanation, surely the question of land use planning and development are beyond land and insfrastructure.

Therefore, in an attempt to understand the region's suburban and its spatial transformation, it seems to be not enough to use the theories of the construction of the region as 'menu' provided by von Thunen, Christaller, Perroux, and Burgess. Also, the institutional perspective (institusionalism) can be an alternative identifier in an effort to understand the dynamics of the suburban area. This is important given in certain cases, the impact from government failure is often more fatal due to lower economic efficiency overall, inhibits growth and equalization (Rustiadi, et al., 2011).

Urban development that stems from coordinated planning and investment by coalitions of developers, bureaucrats, citizens, and politicians can lead to cities that are centers of growth, innovation, and productivity (World Bank, 2017). In contrast, the weak urban planning such as mis-allocative investment and 
limiting connectivity between neighborhoods and/or residential area, as well as the emergence of practices of exploitation system to generate profits for himself on its own, ultimately impeding an urban area/suburb in an attempt to reach the economic growth the region. Such growth is not only leads to convergence, but also can provide the assurance of equitable distribution for the society.

Moreover, the suburb, as a space, is filled by socio-economic actors whose behaviour is undivided, but rather mutually interacting. In the context of institutional, every actor certainly has its own interests. At the time the interest was met, the clash of interest occurred (Yustika, 2006). At this point, Ostrom's perspective (1990) can be used to become explanatory framework how the clash of the interests addressed.

In the end, this elaboration will lead us to further clarify it into a more factual empirical research. Although it is not easy because of the concerns the availability of the data, it is not impossible to do. Therefore, this article challenges the academics to review institutional roles, either formal or informal in relation to the transformation of suburb with all the dimensions of the issue, either economic, social or spatial. Concretely, a number of issues that can be examined include: government spending at the level of municipal urban infrastructure, in terms of strategies of surviving residents who work in the agricultural sector, small-scale formal institutional role towards the governance of land, housing and others.

\section{Conclusion}

It can be understood, from the institutional perspective, land transformation in Indonesia were caused by regulatory decentralization. These changes cause many areas to extract themselves and formed a new administrative area. As a result, many of those propose to form the "downtown" area (municipal). Data shows, the number of municipal area increased from 61 to 94 . This increase reached $54 \%$ since the era of decentralization and autonomy to be implemented. Changing the status of the territory will also change the structure of social, economic and spatial locality. In that regard, it is evident that the dynamics of land in suburban areas can no longer rely on the old ways. Because the fact remains that today's planning and development of land not only involves the role and behaviour of households and companies, but also institutions,. both formal and informal.

\section{Acknowledgment}

This article is a 'little piece' of dissertation entitled "Developing Policy and the Governance of Sustainable Residential Area in Suburban Indonesia" in Regional and Rural Development Planning Sciences Bogor Agricultural University. Upon the publication of this article, thank you delivered to all supervisors who has been doing supervision and examination on this article.

\section{References}

Andrada, A.F.S. (2017). Understanding Robert Lucas (1967-1981): His Influences and Influences, EconomiA, May-Augustus 2017: 212-228.

Ann, F. (2013). Defining Suburbs, Journal of Planning Literature, 27, No. 3: 270-281.

Astuti, W., et al. (2012). Identifikasi Fenomena Urban Sprawl di Kec. Cimanggis Kota Depok. Laporan Penelitian, Bogor: Fakultas Teknik Universitas Pakuan.

Blair, J. P. (1991). Urban and Regional Economics, Irwin, Boston, MA.

Caballero, G., \& Onate, D.S. (2016). Why Transaction Cost are so Relevant in Political Governance? A New Institutional Survey, Brazilian Journal of Political Economy, Vol. 36, No. 2 (143): 330-352.

Chan, G.L., Lin, T.A., Leindely, Jeffery, A., (1992). Understanding Suburban Commuting Chacaracteristics: An Empirical Study in Suburban Dallas, Transportation Planning 
and Technology, Vol. 16: 167-193.

Clark, G.E. (2007). Unsustainable Suburbia, Environment: Science and Policy for Sustainable Development, Vol. 49, Number 8: $3-8$.

Curley, A.M. (2005). Theories of Urban Poverty and Implications for Public Housing Policy, Journal of Sociology and SocialWelfare, XXXII, Number 2: 97-119.

Day, S. (1996) Suburban Sprawl or Suburban Villages? Defining Planning Principles for New Land Development in Indonesia, Pacific Rim Law \& Policy Association, Vol 5, No. 2: 331-364.

Dietrich, M. (1994). Transaction Cost Economics and Beyond: Toward a New Economics of the Firm, London: Routledge.

Dufek, J., \& Ospala, M. (2002). Analysis of the Basic Characteristics of Demographic Development in and Urban, Suburban and Provincial District in the Czech Republic, Agric Econ, 48, (12): 533-543.

Eltayeb, Y.A., Elhadary, N.S., \& Odoom, F.O. (2013). Development at the Peri-Urban Area and Its Impact on Agricultural Activities: An Example from the Seberang Perai Region, Penang State, Malaysia, Agroecology and Sustainable Food System, 37: 834-856.

Fauzi, A. (2010). Landasan Pembangunan Perdesaan, dalam Chozin, M.A., (penyunting), Pembangunan Perdesaan dalam Rangka Peningkatan Kesejahteraan Masyarakat, IPB Press, Bogor.

Garcia, X., Ribas, A., Llausas, A., Sauri, D. (2013). Socio-demographic profiles in suburban developments: Implications for waterrelated attitudes and behaviors along the Mediterranean coast, Applied Geography, 41: 46-54.

Giyarsih, S.R. (2002). Gejala Urban Sprawl sebagai Pemicu Proses Densifikasi
Permukiman di Daerah Pinggiran Kota (Urban Fringe Area) Kasus Pinggiran Kota Yogyakarta, Jurnal PWK, Vol. 12, No. 1/ Maret 2001, 40-45.

Goix, R.L. (2005). Gated Communities: Sprawl and Social Segregation in Southern California, Housing Studies, March 2005, Vol. 20, No. 2, 323-343.

Gunawan, G. S. (2011). Eksklusifitas Golongan dan Konflik Sosial, Jurnal Dialektika Edisi 08 Tahun 2011, 1-4.

Güzey, $\square$. (2014). Neoliberal Urbanism Restructuring the City of Ankara: Gated Communities as a New Life Style in Suburban Settlement, Cities, 36 (2014), 93106.

Hara, Y., Thaitakoo, D., Takeuchi, K. (2008). Landform transformation on the urban fringe of Bangkok: The need to review landuse planning processes with consideration of the flow of fill materials to developing areas, Landscape and Urban Planning, 84 (2008): 74-91.

Hiles, D.R., \& Schipper, J. (2008). Science, Planning, and the Logic of Suburban Sprawl, Sociological Spectrum, 28: 741-762.

Hirt, S. (2007). Suburbanizing Sofia: Characteristics of Post-Socialist Per-Urban Change, Urban Geography, 28, 8: 755-780.

Huang, Y., \& Jiang, L. (2009). Housing Inequality in Transitional Beijing, International Journal or Urban and Regional Research, Vol. 33.4, December 2009: 936-956.

Hudalah, D., \& Firman, T. (2012). Beyond Property: Industrial Estates and PostSuburban Transformation in Jakarta Metropolitan Region, Cities, 29: 40-48.

Hwang, S. (2015). Residential Segregation, Housing Submarkets, and Spatial Analysis: St. Louis and Cincinnati as a Case Study, Housing Policy Debates, Vol. 25, No. 1, 91- 
115.

Jati, W.R. (2015). Bonus Demografi sebagai Mesin Pertumbuhan Ekonomi: Jendela Peluang atau Jendela Bencana di Indonesia?, Populasi, Vol. 23, No. 1 (2015): 1-19.

Kathryn, M., et al. (2009). Disparities in Urban Neighborhood Condition: Evidence from GIS. Measures and Field Observation in New York City, Journal of Public Health Policy, 30, 264-285.

Lambert, T.E., Catchen, J., \& Vogelgesang, Victoria. (2015). The Impact of Urban Sprawl on Disaster Relief Spending: An Exploratory Study, Journal of Economic Issues, Vol. XLIX, No. 3 September 2015: 835-864.

Leicsh, H. (2002). Gated Communities in Indonesia, Cities, Vol. 19, No. 5, 341-350.

Lestari, A., \& Dharmawan, A.H. (2011). Dampak Sosio-Ekonomis dan Sosio-Ekologis Konversi Lahan, Sodality: Jurnal Transdisiplin Sosiologi, Komunikasi, dan Ekologi Manusia, April 2011: 1-12

Lewyn, M. (2017). Government Intervention and Suburban Sprawl: The Case for Market Urbanism, New York: Springer.

Liu, Z., \& Liu, L. (2016). Characteristics and driving factors of rural livelihood transition in the east coastal region of China: A case study of suburban Shanghai, Journal of Rural Studies 43: 145-158.

Mikelbank, B.A. (2006). Local Growth Suburbs: Investigating Change within the Metropolitan Context, Opolis Vol. 2, No. 1: 1-15.

Mugavin, D. (2002). Suburban Singapore: Landscape of Change, International Journal of Urban Sciences, 6(2): 106-117.

Myung, J.J., Jae Ik Kim, Jin Hwi Kwon, \& Ji-Eun Jeong (2013). The effects of high-density suburban development on commuter mode choices in Seoul, Korea, Cities, 31: 230-238.
Newman, B.J., et al. (2013). The "Daily Grind": Work, Commuting, and Their Impact on Political Participation, American Politics Research, 42: 141-170.

Ortega, A.A.C. (2012). Desakota and Beyond: Neoliberal Production of Suburban Space in Manila's Fringe, Urban Geography, 33: 1118-1143.

Ostrom, E. (1990). Governing the Commons: The Evolution of Institution for Collective Action, Cambridge University Press, UK.

Priyarsono, D.S. (2017). Membangun dari Pinggiran: Tinjauan dari Perspektif Ilmu Regional, Journal of Regional dan Rural Development Planning, 1 (1): 42-52.

Ragusett, J.M. (2014). Is Urban Sprawl Good for Minorities?, Housing Policy Debate, Vol. 24, No. 2, 335-363.

Rustiadi, E., Saefulhakim, S., Panuju, D.R. (2011). Perencanaan dan Pengembangan Wilayah, Jakarta: Crestpent Press dan Yayasan Pustaka Obor.

Schram, A.J.H.C. (1991). Voter Behavior in Economics Perspective, Springer-Verlag: Paris.

Serlin, M.A., \& Umilia, E. (2013). Faktorfaktor yang Mempengaruhi Masyarakat dalam Memilih Lokasi Hunian Peri Urban Surabaya di Sidoarjo, Jurnal Teknik Pomits, Vol. 2, No. 2, (2013): 143-148.

Silva, J.V., et al. (2012). High mortality, violence and crime in alcohol dependents: 5 years after seeking treatment in a Brazilian underprivileged suburban community, Rev Bras Psiquiatr, 34: 135-142.

Sinclair, R. (1967). Von Thunen and Urban Sprawl, Annals of the Association of American Geographers, Vol. 57, 1967-Issue $1,72-87$.

Smadja, O.P., \& Torre, A. (2017). Retail decentralization and land use regulation 
policies in suburban and rural communities: The case of the Ile-de-France region, Habitat International $\operatorname{xxx}(2017)$ : 1-12.

Solow, M.R. (1956). A Contribution to the Theory of Economic Growth, The Quarterly Journal of Economics, Vol. 70, No. 1, 65-94.

Sonmez, I.O. (2009). Re-Emergence of Suburbia: The Case of Izmir Turkey, European Planning Studies, Vol. 17, No. 5: 741-763.

Surya, A. (2006). Arus Penglaju dan Moda Angkutan Darat di Kota Metropolitan Indonesia, Jurnal Perencanaan dan Pengembangan Wilayah Wahana Hijau, Vol 1, No. 3: 84-88.

Vaughan, L., Griffiths, S., Haklay, M., Jones, C.E. (2009). Do the Suburbs Exist? Discovering Complexity and Specificity in Suburban Built From, Transactions of the Institute of British Geographers, London, unduh 25 Februari 2017, http://discovery.ucl. ac.uk/16144/1/16144.pdf,

Widhyharto, D.S. (2009). Komunitas Berpagar: Antara Inovasi Sosial dan Ketegangan Sosial (Studi Kasus Komunitas Berpagar di Provinsi DI. Yogyakarta), Jurnal Ilmu Sosial dan Ilmu Politik, Vol. 13, No. 2, November 2009, 204-230.

World Bank (2009), Reshaping Economic Geography, World Development Report 2009, Washington DC.

World Bank (2017). Governance and The Law, World Development Report 2017,
Washington DC.

Yandri, P. (2013) Kepuasan Masyarakat terhadap Pelayanan Kelurahan setelah Pemekaran di Tangerang Selatan, Jurnal Liquidity, Vol. 2, No. 2: 151-159.

Yandri, P. (2014) Residential Area and Income Inequality in Suburban Indonesia, Indonesian Journal of Geography, Vol. 45, No. 1, June 2014, 69-77.

Yandri, P. (2015). Residential Area in Suburban Indonesia Today: Conflicts and the New Pattern of Residential Segregation, Presented Paper, The $5^{\text {th }}$ International Conference of Jabodetabek Study Forum, "Sustainable Megacities: Vulnerability, Diversity, and Livability", IPB International Convention Center, 16-18 March 2015.

Yandri, P. (2017). The Political Geography of Voters and Political Participation: Evidence from Local Election in Suburban Indonesia, Indonesian Journal of Geography, Vol. 49, No. 1, June 2017.

Yustika, A.E. (2006). Ekonomi Kelembagaan: Definisi, Teori \& Strategi, Malang: Bayumedia Publishing.

Zhao, P. (2016). Planning for social inclusion: The impact of socioeconomic inequities on the informal development of farmland in suburban Beijing, Land Use Policy 57: 431443. 